No. 174

Deathscapes of the Malay Martial Artist

Douglas Farrer

\author{
Department of Sociology \\ National University of Singapore \\ 11 Arts Link \\ Singapore 117570 \\ E-mail: $\underline{\text { socfds@nus.edu.sg }}$
}

ISSN 0129-8186

ISBN 981-3033-68-1

All rights reserved 2005 


\title{
Deathscapes of the Malay Martial Artist
}

\author{
Douglas Farrer
}

\begin{abstract}
This article traces the connections between death and the afterlife as configured through the Malay martial art silat, in Malaysia, Singapore, and the Riau Archipelago. The practice and performance of silat are addressed here through aspects of non-material and material culture, including ritual, dance, jewelry, symbols, and art. Silat is designed to physically and spiritually transform the silat practitioner, and relinquish their fear of death and dying. This transformation is partly accomplished by calling (berseru) the shadows of the potent dead. However, the contemporary medicalization of death may preclude the possibility of noble death. To illustrate the disjuncture of deathscapes, I contrast the agonizing death of a silat master, compared to the cemetery ordeal through which he put his son.
\end{abstract}

Key words: Deathscapes, Malay martial arts, necromancy, noble death.

\section{Introduction}

In this article I examine the Malay martial art silat through its concept of death and the shadow soul (bayang), and attempt to relate this to the urobos, the snake eating its own tail, which is a symbol of transformative regeneration. ${ }^{1}$ Silat masters (guru silat) are the gatekeepers of Malay war-magic, and as experts in the field of death they are concerned with how to live, heal, die, and kill. Silat is a combat strategy that does not focus only on unarmed combat, but also values bladeusage, and magical powers. If death is considered as a stage between this life and eternity, then the spirits of the noble dead may appear to watch over the living. The ability of the guru silat to peer into the nether world, and call shades, places them on a par with the shaman, with the caveat that Islamic silat masters are prohibited from entering trance. I sketch the 'deathscapes' of several different types of silat, which although dissimilar in some respects share essential characteristics in their ideas of noble death, and then I consider the actual death of a silat master. ${ }^{2}$ Prior to commencing these sketches I turn to some conceptual and theoretical issues. ${ }^{3}$

I use the term 'noble' in the broad sense to refer to a worthy or illustrious person and not in the restricted sense to those of royal or aristocratic birth; 'noble' as (potentially) an achieved, and not necessarily an ascribed status. Historically the Malay societies of Peninsular Malaysia, Singapore, and the Riau Archipelago were stratified into three classes: the royal family (sultans 
and rajahs), the aristocracy (bangsawan), and the peasants (ra'ayat). ${ }^{4}$ One way to achieve status in Malay society was to become a renowned guru silat - a kind of headman. In Malay (Bahasa Melayu) the language used for the ruler is different from that used for ordinary folk. To paraphrase Laderman, the ruler never eats (makan), he regales himself (bersantap); disdaining sleep (tidur), he reposes (beradu); he does not die (mati), he is wafted aloft (mangkat) (Laderman 1983: 61). Formerly, the ruler provided the exemplary model for being or becoming Malay (Melayu) (Andaya, and Andaya 2001: 47), and this includes the adoption of Islam, sometimes in specifically Sufi varieties (Alatas 1985; and personal communication 17 June 2005).

Sufi Malays view death as a transformation, "an opening to go through" rather than as the ultimate culmination of life: one moves not from life to death, but from life to Eternal Life, through death. ${ }^{5}$ However heroes, martyrs, sultans, and saints can avoid death altogether, an idea well known to Islam, if controversial: "We believe that Malaysia is protected by these people. In [the Holy] Quran it says that people who fight in the service of Allah never die...though you see them die they actually don't die" (Khalid: from fieldnotes).

Hence the reality of death is separate from the appearance of death. Christ is an example of this, as orthodox Muslims, Malays included, deny the death and resurrection of Christ, saying that he only appeared to die on the cross. At certain key moments in history powerful "immortals" will be present on earth to do battle with the forces of evil. The present era is "the

beginning of the end" of time, when all the power of Evil is to be unleashed upon the world: demons, jinn, gargoyles, Shaytan, and the anti-Christ (Dajal) are amassing, ready for the final battle. ${ }^{6}$ The Prophet Isa (Jesus) will return, and the world must unite under the last Caliph. Then Judgement Day will finally be upon us. As the legions prepare for battle the immortal warriors, saints (Shaykhs or wali), Caliphs, Prophets, and other friends of God are already among us, and it is only because of the tireless struggle of the Forces of Good that the Forces of Evil are momentarily held in check.

\section{Deathscapes}

By 'death' I do not mean simply the cessation of 'animal life', but death as conceived by the living. ${ }^{7}$ For conceptions of death, I coin the term 'deathscapes', by which I mean an orientation towards death that posits such "virtualities" as an 'ideal death', a 'good death', or a 'bad death', and the 'time of death', along with a set of shared understandings concerning ancestors, those

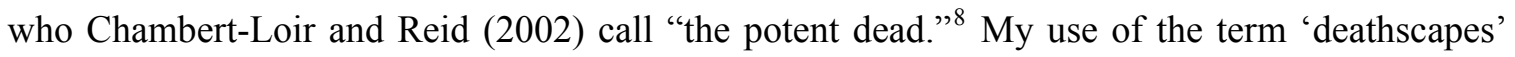
stretches it beyond its use in cultural geography where it refers to cemeteries, memorials, and 
monuments (Hartig, and Dunn 1998), and "...avoid[s] the narrow strictures of examining deathscapes as a space-utilizing phenomenon..." as recommended by Kong (1999: 9), since whilst I acknowledge the term's applicability to landscape, I want to use it more generally to discuss objects as well as ritual, practice, and performance.

Like ethnoscapes, mediascapes, technoscapes, financescapes, and ideoscapes, discussed by Appadurai (1996: 33), death flows all around us, giving rise to all manner of interpretations, rituals, and practices, including Parry's (1982: 74-110) bizarre Aghori aesthetic, who lives in the cemetery in a mud hut walled with human skulls, devours human flesh, faeces, and dog's urine, and consorts with menstruating prostitutes; Metcalf and Huntington's (1991: 209) Americans, where "self-made men are reduced to puppets" pumped with formaldehyde, and put on display; and Geertz's ([1960] 1976: 72) sober Javanese, who bury their dead quickly, before the sun sets. ${ }^{9}$ Although Westerners, according to sociologists, psychologists, and anthropologists, may live 'in denial' of death (Becker 1973; Hayslip 2003: 34-42; Littlewood 1993: 69-84; Metcalf, and Huntington 1991: 110), highly publicized "megadeaths" (Rosenberg, and Peck 2003: 223-236), such as the ongoing slaughter in Iraq, and the immense devastation of the recent Tsunami, prevent death from taking much of a holiday, at least not a very long one (contra Goldberg 1998).

After the Second World War and during the years since Hertz's [1905-06] (1960) essay Contribution à une étude sur la représentation collective de la mort was translated into English, there has been a tremendous resurgence in the literature on death. There is now so much death literature that Bryant et al. (2003) have recently produced a two volume encyclopedic handbook to try to organize it. I am not going to attempt to summarize the anthropological literature on death here, but instead signal my work in relation to some of the classic and recent contributions. Those familiar with the literature may immediately perceive 'deathscapes' as a challenge to the "ideology" of Bloch and Parry (1982), the "mentalités" of Ariès (1978), and the "collective representations" of Hertz (1960), and Metcalf and Huntington (1991).

First, I find the concept of 'deathscapes' preferable to 'ideology', because the term ideology still conjures up the Marxist avatar of 'false beliefs', one of the seventeen varieties noted by Eagleton (1991: 1-2), whereas I am not concerned with stipulating the truth or falsity of indigenous beliefs. It may be objected that this is a crude reading of 'ideology', but even a more sophisticated version, say 'particular ideas represented as universal', sets the social scientist in a Olympian position vis-à-vis the notions of death of the other, and situates the 'Other' as somehow not really real.

Second, as Metcalf and Huntington point out, Ariès's (1978) "mentalités"-the European reactions to death surveyed over several centuries, "the attitudes characteristic of the 
epoch," can be subjected to the same criticism as the culture and personality school in anthropology, i.e. it is too subjective (Metcalf, and Huntington 1991: 20). Here I would hasten to add that by 'deathscapes' I do refer to a configuration of ideas that are historically situated and generated, but this does not make them a 'mindset', a vulgar term of pop psychology, which I would regard as akin to a crude employment of mentalités. More fundamentally, I use deathscapes to refer to an embodied set of practices, rather than to refer to something subjective, mental, or imaginary.

Third, 'collective representations' was ever the substitute for the abandoned conscience collective, and my problem is that in the rituals and practice of the Malay martial artist, and in the artifacts of their material culture, what is important is not what is being 'represented', where one thing stands for another, symbolizing something else; instead something is happening, something that may be constituting the social order, rebelling against it, ignoring it completely, or satirizing it, as the case may be, in other words, something part of an active constitution of self and identity, both as transformed and maintained, and not merely a passive reflection.

My rejection of collective representations is influenced by Gell's Art and Agency in which he eschews Saussurian semiotic interpretations of art, in favor of reading the art object in terms of what it does, rather than what it represents (Gell 1998: 6). In order to accomplish this Gell adopts Peirce's (1991) tripartite scheme of 'index', 'icon', and 'symbol'. To briefly explain, and here I greatly simplify Gell (1998: 13), the 'index' points to something else (smoke points to fire) and does not 'represent' it; an 'icon', say a religious fetish in the form of a goddess statue is an avatar of the vigilant goddess, and is not merely her representative; and lastly, a 'symbol' represents, or stands in for, something else.

Kapferer, independently of Gell (as far as I am aware), develops a strong criticism of collective representations, and pushes the question of ritual beyond the problem of order to the transformation of meaning and identity through ritual interaction. According to Kapferer " $[t]$ he dynamics of rite in the context of embodiment involve not only the playing out of structure but its creation - the point that Turner stressed in his work, thus countering a static Durkheimian representational orientation that has clogged much anthropological discussion of rite" (2004: 41). For Kapferer, ritual goes beyond representation, symbol is beyond sign, and he argues that an approach needs to be adopted toward ritual that "concentrates on ritual as a virtuality;" that understands it from its own internal point of view, and not in relation to external parameters (Kapferer 2004: 46). Therefore, there is no need to continue to tie the symbols of the living and the mourners, to the corpse and the burial, to the soul and the dead (Metcalf, and Huntington 1991: 83) to find out what they 'mean', or for Hertz (1960: 58) with his talk of survivals, what 
they 'meant'. Instead we should attempt to envisage how the virtual space and time opened up by ritual leads to the creation of meaning through the change in the participants. Seen like this, ritual is a dynamic virtual process that can "transform the existential circumstances of persons in nonritual realities" (Kapferer 2004: 47).

My question here is, what if the virtual transformative properties of rituals, once enacted, are misunderstood by, or unknown to, or ignored by others, who despite the best of possible intentions may 'betray' the patient? (Goffman 1961: 139-143). The article goes on to examine this question, which I frame in term of 'discrepant deathscapes', or the same thing, but put another way, a 'disjuncture' of deathscapes, which are simultaneously real and virtual.

Data used for this account was gathered from several Malay guru silat, their families, and students (pesilat) in Peninsular Malaysia, Singapore, and the Riau Archipelago between 1996 and 2004. ${ }^{10}$ During this time I learned several styles of silat, as part of my ongoing "performance ethnography" (Zarrilli 1998: 255n.6). ${ }^{11}$ I also attended the deathbed of guru silat Wak Sarin, who died in 2002. Salim's father, Mokri, who is now in his nineties, recently called the family together to witness his performance of death (he survived). Salim's son, Masri, related the training in silat given to him by his late father, which involved an ordeal of lying in an open grave for eight consecutive nights. ${ }^{12}$ To attempt to understand the Malay art of silat, and their view of "noble death', I have also consulted guru silat Muhamad Din Muhamad (henceforth Pak Din), and Ariffin Yeop Mahidin (henceforth Pak Ariffin). ${ }^{13}$

The deathscapes discussed here are those of the masters of the Malay martial art. Their 'thanatology', their 'virtual world' of death, what I refer to as a 'deathscape', is comprised of several elements, including the principles of how to kill, and how to survive, as well as of how to die a 'good death', and cause a 'bad death', alongside rituals and performances meant to entertain, respect, and summon the ancestors. ${ }^{14}$ For the guru silat the idea of a 'good death' is part of their aesthetics of death, and 'noble death' refers to a dignified death within these parameters. I inquire whether there is a disjunction between overcoming the fear of death, which is encountered and inculcated as part of the silat 'rehearsals of death', and the actual experience of death, as it occurs predominantly in the modern hospital setting where medical staff and significant others (next-of-kin) exercise considerable control over the treatment of the patient. I then question the possibility of having a noble death under these circumstances, and ask to what extent modernity precludes a 'traditional' noble death. 


\section{The Art of Silat}

Silat is a martial art and a Malay folk dance. ${ }^{15}$ According to guru silat Pak Ariffin silat is not the "art of war, but the Malay art of stopping war" (cf. Wiley 1993). ${ }^{16}$ Furthermore, he says the functions of silat are "to teach people to defend themselves, to attack others in a controlled way, to teach the community defense, and to teach people to die happy. You must be happy in life to die happy." Guru silat say that "[s]ilat must teach you how to live properly, with Islam or other religion, in order to prepare you for death" (Pak Din). ${ }^{17}$ Hence silat, as with other Southeast Asian performative genres, is a vehicle of proselytization (Keeler 1987: 234; Tuan Ismail Tuan Soh 1991: 67).

The origin myths of silat often involve a whirlpool generated by a waterfall. Some myths say a man invented silat, others say a woman. One mythological account of the origin of silat relates the story of a woman who had withdrawn from her husband after a violent beating. Later, on the way to (or back from) the waterfall, she witnessed a fraught battle between a crane and a snake. When she got home she thrashed her husband, who subsequently became her first silat pupil (cf. Draeger [1972] 1992: 9-10: Maryono 2002: 34; Pauka 1998; 27-28; Sheppard 1972: 140; Tuan Ismail Tuan Soh 1991: 36-37).

Space prohibits me from a lengthy description of silat as a combat discipline. It is comprised of two fundamental aspects, which in Malaysian silat are called bunga (flower), and buah (fruit). Below I discuss bunga and buah to provide a description of the art, useful to readers who may not have seen it. ${ }^{18}$

The movements of bunga, often danced at Malay weddings, are graceful, stylized, smooth, and circular. The performance of bunga looks somewhat like tai chi, only less angular, less protruding, and the timing is more varied than the slow meditative tai chi. ${ }^{19}$ It's as if the embodied aesthetic of tai chi were masculine, as compared to the feminine aesthetic of Malay silat (silat Melayu); or as if the shadow of a tai chi expert were projected in the movement of silat. Some moves enact Islamic prayer (doa), or Hindu prayer (sembah), others summon energy from the performer, environment, or opponent; yet others mimic the movements of animals, or human beings engaged in quotidian activities such as sewing, combing their hair, or chopping wood. ${ }^{20}$ Bunga disguises the lethal arsenal of silat. Beautiful, yet deadly, it is the flowery, graceful, aesthetically pleasing dance of silat that differentiates silat from other martial arts. The continuous twisting and curling over of the hands echoes Indian and Javanese dance, and exemplifies its 'feminine' beauty. Initially, I could not see how bunga could possibly be deadly, until a wedding silat expert showed me the same elegant steps, but whilst holding a razor. 
Buah is a method to teach the practical application of "combat strategies" (Rashid 1990: 63) to take down, and lock an opponent. Buah are 'combat scenarios', which, to employ Goffman's (1974: 10) term, rehearse a series of "strips" of combative behavior and premeditated responses. The strips are found in bunga, and hence buah teaches the application-buah is the fruit of the flower in the garden of silat (silat sekebun). To execute a takedown, or lock an opponent, an 'entry' against a preconfigured attack (armed or unarmed) is required in the form of a technique that puts the opponent in a position in relation to the pesilat where a limb, the head, or torso (or combination of these) can be struck and manipulated into a compromising position to give the pesilat the advantage. Buah is less graceful than bunga, but the moves are executed without brute force, appearing effortless. Some Indonesian styles of silat often refer to buah as pukulan, and may emphasize the strike (pukul) rather than the takedown; however, the striking of vulnerable points is implicit in buah, which also translates as "testicles." The practise of buah against different opponents, where one individual acts as the attacker and the other as the defender, gives the pesilat skills of distance, timing, footwork, posture, and body mechanics. Buah is a form of rehearsal in a theater of combat, and gives the pesilat an array of responses to any given attack. Not all buah end in locking the opponent, as some simply knock them down with a sweep (sapu), others may end up locking the opponent, and then enacting a strike or kill. ${ }^{21}$ In Peninsular Malaysia, buah are given names like kuda gila (crazy horse), amok (amok), and cinabuta (blind Chinese).

\section{The Aesthetics of Death}

To learn more about 'the unseen realm' (alam raib) of spirits (jinn), the guru silat advise their pupils to sit with those who are dying, and carefully watch their last moments, listen to their last words, and observe their breath. ${ }^{22}$ Was the last breath in or out? Controlled, or gasping? Look into their eyes, are they staring far away, or darting around the room, perhaps seeing what we do not? This eye behavior, and the slipping in and out of consciousness, is considered proof of the reality of the spirit realm, a realm that is also entered through sleep, and experienced in dreams. A 'good death' is considered a willing, timely, and voluntary entry into this other dimension.

A guru silat is said to have "died a beautiful death in Singapore, with exact time, and exact style." This provides an example of the 'aesthetics of death', where deaths are divided into 'good deaths' and 'bad deaths' (cf. Block, and Parry: 1982: 15-18; Bradbury 1999: 142-6, 159-

60; Parry 1982: 82-3). ${ }^{23}$ The idea of "exact time and style" means that death is peaceful, its time foreseen, and the time of death may be accepted or delayed temporarily. Here death is not seen as 
annihilation, but as transformation. Transformation occurs at several levels, including spiritual, and social. Thus, a great warrior (pendekar) may attain the noble status of a Saint (wali), providing an example of status mobility in what was previously a stratified patrimonial society (Errington 1989: 97-98; Gullick 1958: 22). ${ }^{24}$ To die in battle (mati jihad) for your country, cause and belief, provides another example (with mangkat) of noble death, but one that is specifically Islamic. In mati jihad the usual burial rituals of cleansing and redressing the corpse are suspended, and the soul is said to directly enter paradise.

Gradual signs of impending death include the hair turning white, balding, aging, wrinkling, and losing teeth, fitness, and strength. All these changes show that "there is a clock ticking away the moments of your life" (Pak Din). However, some Sufi and silat masters (often one and the same) seem relatively immune to these gradual symptoms of impending death, and live to a ripe old age looking relatively fit, slim, and youthful. Wali are said to mysteriously disappear rather than die, and directly enter the company of the immortals (arwah), returning to the mortal realm in times of need, or at their leisure to teach silat. It comes as no surprise then, that the grave (keramat) of the legendary Malay hero Hang Tuah, which grows longer every year, is known to be empty. ${ }^{25}$ Other noble souls travel to the same place, but take the route of death. By either route the principle is established that immortality is possible for the noble soul, who may chose between death and disappearance.

That silat elders were reputed to be able to predict the day of their death, and to be able to postpone it, is a particular example of a wider practice. One method is to wear earrings made from petrified dew. Another method is to insert the rare stone of petrified dew (geliga embun) under the skin. ${ }^{26}$ The art of inserting precious magical things into the body is known as susuk, a favourite of Malay love magic, where men and women enhance their beauty through enchanted supplements. $^{27}$

It is necessary to turn to the negative example, to the 'bad death', or the 'ignoble death'. They are not identical, though the difference may be subtle. Suicide provides an obvious example of a bad and ignoble death, as suicide is taboo in Islam, and deemed a passport to Hell. 'Bad death' would include any sudden or unanticipated death, such as the loss of life by accident, or murder, or during childbirth. During birth, the death of a mother, or child, or both, results in a female vampire (pontianak), and for the failed issue, an evil spirit (toyol). In this case it is only the souls of those who have died a calamitous death, shrouded in misfortune, which are reanimated as evil beings. ${ }^{28}$

The down side of susuk is that when death eventually does occur, it is slow and agonizing, leaving one begging for release. ${ }^{29}$ Pak Din says " $[w]$ hen you accept death it becomes 
your friend, it gives you all the signs and an opening to go through. If you don't accept [death] then you have to bang your way through." Once death has occurred, Malays tend to accept it quietly, and later, after the burial, may seem perplexed if you ask them if they feel sad, saying "[w]hy should I feel sad? He has gone to some place better" (Pak Ariffin, referring to his late father).

Although there are a myriad of ways to end a life in silat, including snapping the neck, or spine, strangulation, and striking vital points (nadi), decapitation is a prime example of an 'ignoble death'. One technique resulting in decapitation (there are dozens) is 'cinabuta'. This is a technique using the traditional attire for men, a sewn cloth skirt (sarong), which when rolled tightly can be used like a heavy whip, or held in both hands used to block and catch weapons or limbs. The sarong is especially effective as a weapon when it is implanted with magical rocks, or meteorite. The sarong is rehearsed against an attacker armed with a parang (long knife), where after blocking the downward chop of the parang under the elbow, a turning movement is used to trap the attacker's arm. The cloth is simultaneously wrapped around the attacker's head, covering the eyes. From behind, they are tripped to the floor, and whilst they lie prone the parang is removed from their grip. The coup de grâce is one of rehearsed decapitation, whilst the victim is pinned to the floor with their head held, and their eyes covered. It was hinted to me that this technique is called "blind Chinese" in reference to the $13^{\text {th }}$ May 1969 ethnic riots in Kuala Lumpur (cf. Horowitz 2001: 98), but the technique is most likely considerably older than that. ${ }^{30}$ More recently, in Kampong Medan, in 2002, a dispute between a Malay wedding party and an Indian funeral procession escalated into an ethnic riot lasting several days, and was ended, so I am told, by a guru silat who decapitated the headman of the Indian village. This suffices to make the point as to what is an ignoble death, one that has relevance for contemporary conflict zones. ${ }^{31}$

Silat masters have practical and mystical means at their disposal to cause death. They have been documented to kill their foes with a single slap (penampar) (Rashid 1990: 74). This may provide a non-aesthetic reason for the prodigious size of the stone and metal rings many Malay men wear upon their fingers. Instead of turning their hands into rocks, as was the way of kung fu masters, they wear rocks upon their hands. Elders of a Sumatran style of silat called Silek Bayang (shadow silat) are said to be able to kill from a great distance, sending "supernatural" force to targets of the head, neck, stomach, or the navel of the opponent (Maryono 2002: 229). More dramatically, some silat masters claim to be able to kill with a single glance. Silat practitioners eschew notions of purely unarmed combat, and are experts with all kinds of blades. The most famous Malay weapon is the sinuous keris, said to have a soul of its own, and the power to harvest the soul of the enemy at the moment of death, storing it in the blade. Hence, the 
more people the keris has slaughtered, the more potent and valuable the weapon, which is said to enhance the ability of the fighter using it.

There are plenty of historical data regarding the efficacy of silat in actual combat: here one example must suffice. After the Second World War, during the lawless interregnum, not only were the Malays able to withstand the Malaysian People's Anti Japanese Army (MPAJA) attacks, but they launched reprisals against Chinese villages. As Cheah states "[t]hey were able to slaughter and terrify the Chinese villagers without check until remnants of Chinese settlements fled to larger Chinese towns for refuge. Neither Chinese villagers nor the MPAJA could stop them nor understand their fanatical force" (Cheah 2003: 296). This "fanatical force" was partly generated through a belief in invulnerability, and faith in Islamic chanting (dhikr), prompted by charismatic leaders such as Kiyai Salleh, whose parang panjang (sword) alone was reputed to have claimed 172 heads (Al-Attas 1963, in Cheah 2003: 208). ${ }^{32}$ Cheah (2003: 227) also documents various accounts of how Datuk Onn bin Jaafar, at the bidding of Sultan Ibrahim of Johor, managed to prevent Kiyai Salleh, the leader of the 1,600 Sabilillah (Holy War) Army of the Red Bands from attacking Batu Pahat town-hence silat can be defined as the art of stopping war, and not just as the art of murder.

\section{The Malay Deathscape}

My informants are Muslims of the Sunni, or 'orthodox' school of Islam. They believe that there are three stages upon death. These are the interrogation in the coffin, the Day of Resurrection, and Eternal Life, either in the Garden of Heaven, or the Fires of Hell. What happens to the soul upon death is less than clear-cut. The soul fragments upon death; the parts that coalesced in life to form the self (diri) including the roh (the individual identity from the spiritual breath of God), the nyâwa (the part that goes to heaven or hell), the nafs (the essence that binds the soul to the body), and the body (clay), are now distributed in different realms (cf. Chittick 1992; Endicott 1970). This is complicated by the Malay belief in the seven-fold soul, which includes the shadow soul and the reflection soul, which are together known as bayang (Endicott 1970: 78; Skeat [1900] 1984: 50n). An individual element of the soul, as well as the combined whole, may be referred to as sěmangat (Benjamin 1979: 11; Endicott 1970: 79).

Shortly after the birth, the placenta (uri) is buried near the home the baby will live in: if it is a boy the afterbirth is called adik (younger sibling), if a girl kakak or (elder sister). The 'twin' shares a spiritual connection to the newborn baby, important in childhood, and later life (cf. Laderman 1983: 178-9). Therefore, as in Java: 
The burying of the umbilical cord is a serious matter. One woman blamed the death of her child, in convulsion after forty days of life, on the fact that the dukun did not put enough salt on the umbilical cord when she buried it, and so it 'came up' and the child died. The cord and the afterbirth, coming as it does after the birth of the child, is considered to be his spirit younger brother, while the amniotic fluid which proceeds him (it is thrown up into the air) is considered to be his spirit older brother. For the first thirtyfive days they remain near the child and protect him against illness, the first underground, the other in the sky. Afterwards they may wander, but they remain one's guardian spirits. It takes, however, extended mental concentration, fasting and wakefulness - what the Javanese call tapa - to get into contact with them (Geertz 1976: 46).

Of course, the burial of the placenta can only occur if the placenta is available, and according to Peletz (1996: 219) in Malaysia it is not, which gives an example of divergent 'birthscapes' between the Malay practice, and that of the hospital. For many years the placenta was be deemed 'biowaste' and disposed of "in the trash" (Peletz 1996: 220), which was formerly common in England, except (to the sheer horror of my informants) where some parents would fry the placenta and eat it, as it is supposed to replace the lost blood of the mother.

Upon death (kematian) Malays believe the corpse is questioned by the Angels of Death (Malaikat). As the last coffin-bearer takes his seventh step away from the grave, the angel will ask the corpse inside the coffin "Mara buka," or "who is your God?" The different parts of the corpse will each be animated, presumably by their nafs (the roh has departed), and each will tell its story. The mouth will confess to lies or tasting forbidden food or drink, the eyes will own-up to forbidden sights, the legs will testify to stepping in unholy places, the hands will confess unwholesome deeds. The Angels that perch upon our shoulders throughout life, changing shift at dawn and dusk will (from their records) meticulously account for our good deeds and practices (amalan). If the good deeds are found to outweigh the bad, then some say the soul returns to its earthly home, and then gradually ascends to syurga (heaven); others say that before entering Paradise, all souls must be cleansed in the fires of hell (neraka). The more wicked you were in life, the heavier your sins, and the longer the cleaning will take. Until the Angels interview the body, the flesh of the corpse feels pain, and thus burial must take place before sunset (for Hertz this would indicate fear of the corpse). ${ }^{33}$ Given the agony of the corpse, autopsy is an especially difficult and contentious issue for Malay families, who will call a doctor to the house in the advent of a death at home, and not send the corpse to the hospital. 
As the roh ascends it will attend to its previous home to be feasted by a gathering of family and friends (kenduri). This presence may be keenly felt, and even seen (perceived) by the family members, who do not mourn by weeping and wailing, but hold a steady and dignified overnight vigil, offering doa (prayers), specifically the Quranic verse Ya Sin. The kenduri takes place three days after the death, then consecutively, at seven days, forty days, one-hundred days, one year, and finally at three years after the death. At each stage the roh ascends a little higher: shortly after death it hovers about a foot above the ground, by one-hundred days it hovers far away from the family in the distant sky. Each subsequent year the roh will return to watch over their family members throughout the fasting month, only to depart again the night before the kenduri that marks the end of Ramadan known as Hari Raya. ${ }^{34}$ This is a bad time to visit the cemetery, as there are thousands of roh everywhere, and one can become possessed (badi) by the souls of the unfortunate. The omnipresence of the dead ancestors is keenly felt at other times of the year, especially during weddings, births, and circumcisions, where the ancestors attend as unseen guests.

Given the omnipresence of the dead, it is not surprising that their spirits may be called through ritual. In silat, a ritual technology for this purpose is known as seru. According to Rashid "[i]n a silat group, a guru silat may summon different warrior spirits for different students, eventually bestowing different personality forms and characteristics and skills of combat on each one of his students. The gelanggang (training ground) becomes a platform for the symbolic reincarnation of the former warriors and heroes, re-enacting their exploits in a modern world. [...] The guru is the director of this séance of dead heroes" (Rashid 1990: 77). However, this practice is fraught with danger as "if with skill man can control spirits and make them his allies, with carelessness he may well find himself controlled by the spirits in turn" (Benjamin 1979: 16).

In the next part of the article I sketch three ways through which the potent dead may be summoned: through a dance called the belebat, through the opening of a new gelanggang, and through a ritual where the pesilat lies in the grave.

\section{The Four Corner Dance}

Encouraged by Gell (1999: 29-75) to make diagrams of silat, I found a pattern in the footwork performed for the Four Corner dance (belebat). The steps in the belebat conform to the outline of the symbol given in Figure 1. 


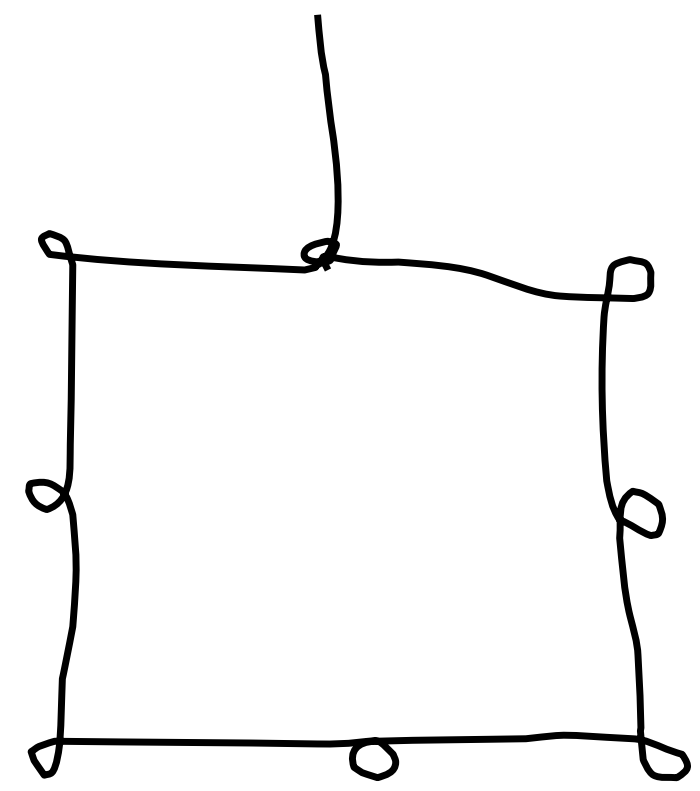

Fig. 1. The belebat footwork pattern

The symbol is shaped like a square with spirals at the four corners, and in the center of each its four sides. In Malay magic, the shape of the rectangle, circle, or square acts as a barrier to contain or fence-off the forces of good or evil. ${ }^{35}$ The diagram above came from Hong Kong, and is drawn from my hand-written translated copy of Grandmaster Yip Shui's unpublished manuscript. Similar symbols are also to be found in books on Chinese magic. For example, de Groot [1910] (1969: 1040) says the tip at the end of the curls signifies a bolt of lightning, and each roll signifies a peal of thunder.

Providing the drawn example, I asked Pak Ariffin about this design. Previously, during fieldwork he said that the belebat is the set that differentiates those who know silat Melayu, which he considers the original and only real silat, from those that don't. His reply to my questions, given by email, was: “As far as I am concerned the Chinese took it from us...if you think it is from Shaolin, then know that Bodhidarma came from Sumatra or Nusantara. ${ }^{36}$ It was taught to me by two teachers, one of them my late father (may Allah bless his soul). THE LAMJALALA. So powerful that if done properly its consequences are on the cosmic level. COSMIC MAN!! LAM-JALALA 1, 3, 4, 6, 8 and 9. The footwork pattern as you call it is LAM-JALALA 8 ... maybe we'll speak about it someday, speaking won't do any good, YOU HAVE TO EXPERIENCE IT!!!!”37

This design is similar to that documented and photographed by Waterson (1990: 95, 120), called the bindu matoga, and found among the Toba Batak of Lake Toba, Sumatra. Waterson [1990] (1997: 95) points out that: 
An eight-pointed design derived from Indian mandalas, which occurs with great frequency as a house-carving motif, represents the eight cardinal points and is called bindu matoga or 'powerful power-point' (Figure 97). This figure was also drawn on the ground at annual rites of renewal, with an egg placed at the centre, and the datu or priests would dance around it with their magic staffs. At the conclusion of the dance, one of the dancers would plunge his staff into the egg. The diagram itself served as a microcosm which could be used in ritual symbolically to destroy the cosmos in order to create it again, with the 'planting' of the datu's staff, which symbolized the 'tree of life' of Toba mythology (Tobing 1956: 173).

In Waterson's photograph of the bindu matoga motif "the whole design is ringed by a naga or snake; both are associated with the underworld" [1990] (1997: 95 fig. 97). Furthermore, "[a]n essential feature of this design are the unbroken lines, maintained by loops at the corners, so that the whole is said to be without beginning or end" (Waterson [1990] 1997: 120 fig. 115). Waterson suggests that these types of designs "are sometimes regarded as inherently powerful and may serve a protective function for the occupants" [1990] (1997: 120).

In a personal communication, Waterson told me that the design is also known to the Karo Batak as Tapak Suleiman (Solomon's Footprint), but why it should be called that among nonMuslims is a mystery. There are several differences between the bindu matoga and the lam jalala, such as the scorpion in the centre of the former, and the way the four central cardinal points are also connected by another diamond shaped square, giving two squares rather than the one. However, Malay guru silat consider the Prophet Solomon (Suleiman) to be the king of the jinn, and Malaysia to be the land of the jinn, as the jinn are said to have settled there en masse after the conquests of Alexander the Great (Iskander). Similar symbols, such as the "Character from the Seal of Solomon" are known in the occult (Shah 1956: 7).

\section{Description of the Dance}

Entry to the dance is through a short series of movements straight ahead, and then the pesilat steps to the right. At each corner the pesilat twirls on the ball of one foot, with the other knee raised, one hand low, and one hand extended above the head. The circles in the center of the lines are performed with the body twisting through three-hundred-and-sixty-degree turns, using the dragon stance (naga berlaboh), where the legs are bent and crossed low, moving into an uncrossed position, and then back into the naga stance facing the other way. The "four corners" correspond to the four elements tanah (earth), api (fire), angin (wind), and ayer (water). ${ }^{38}$ It is performed for royal Malay garden parties by two pairs of players making up a quatrain, with each player exactly mirroring or shadowing his or her counterpart. Up to fourteen people perform the 
dance, with one in the middle. Mirroring, or shadowing the other is difficult, because with the twists and turns in the movements the opponent regularly disappears from view.

In the belebat students are taught to look out of the corner of their eyes, and develop their peripheral vision. They gaze towards the floor, and never stare directly at the opponent. This is a hallmark of silat Melayu. One idea behind this downward gaze is to be able to see simultaneously in front, to the side, and behind: this is required for combat with three or more assailants (pukulan tiga serentat). However, looking downwards may also dehumanize the opponent, as it denies them any opportunity for mutual gaze or recognition. Finally, gazing down allows the silat exponent to see the shadow of the opponent, which is necessary as the shadow is believed to be able to deliver blows, to cause serious injury, even death.

\section{From the Belebat to Haqq}

Pak Ariffin mentions that the lam jalala exists in several varieties, specifically 1, 3, 4, 6, 8, and 9. ${ }^{39}$ Each one of these exists as a separate entity that can be related to a pattern of movements (juros). Each corner of the belebat may represent an element, yet the corners can also be read in Arabic as lam alif; alif being a straight line, and lam the curve that that traverses it. Together this forms the Arabic word $\vee$ (haqq), and this is the badge logo for Seni Silat Haqq Melayu (see Fig. 2).

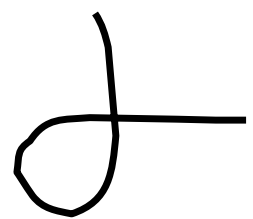

Fig. 2. Corner detail from the belebat footwork pattern.

Haqq is one of the Ninety-Nine names of Allah, and is performed as one of the Sufi dhikr. ${ }^{40}$ There are great mysteries attached to haqq, and I can only briefly touch on some of them here. One meaning is "infinity." If the two ends of a ribbon are joined together, one has the symbol for infinity, where two sides can be shown actually to be one. For Draeger [1972] (1992: 23), who carried out a survey of silat styles in the 1970s, Silat Melayu was the ancient form of silat from which all modern forms draw, but only now exists in crude and attenuated form. The Arabic word 'haqq' roughly translated means 'truth'. But haqq is part of a formula repeated "to find the truth" (ya haqq), and hence the badge is indexical of Pak Ariffin's quest to piece together the fragments of silat Melayu scattered across the Nusantara. This quest is typical of the Malay 
guru silat, and is exemplified by the late Pak Hosni of Singapore, who studied one hundred and eighteen styles of silat, and was the founder of eighteen more. ${ }^{41}$

The quest "to find the truth," and reconfigure silat Melayu, goes beyond the material realm, and into the realm of ghosts and shadows, to enter an altogether different 'magical world' (alam raib). Hence each corner, and each center spiral, mirrors the other, and as the set of movements is performed, the whole is set in circular motion. This danse macabre summons the spirits of the 'noble dead' (or perhaps the jinns through the power of the Prophet Suleiman), and forms an embodied aspect of the practice of seru.

\section{The Urobos}

The next step in my analysis is to trace the link between this complex of ideas, and the urobos, or the snake eating its own tail, which is an important theme in Malay folklore, and appears as a symbol on the Silat Seni Gayong Malaysia badge. Founded during the 1940s, silat gayong is the most popular style of silat found in Malaysia today. The Gayong badge shows a serpent or dragon devouring its own tail, which surrounds a globe, above a tiger's head, set above a pair of keris. According to Skeat in his Malay Magic (or the Malay "folk-religion") "[t]he universe is girt round by an immense serpent or ular Naga, which feeds upon its own tail" [1900] (1984: 6).

Another clue to this Southeast Asian ideational complex is the snake bracelet known as the kayu baha, fashioned like a snake eating its own tail. I was told that: "You put it in a pot outside your house, set in concrete, to ward off evil spirits, especially those from the sea. When someone does magic on you, and they throw the remains into the sea, they say you will never recover. Also people wear it on their wrist for health: to take away sickness" (from fieldnotes). The bracelet or kayu baha is made from a sea fan, which is a kind of coral common in deep-sea water. The snake is a symbol of the jinn, the earliest creation beside human beings, which exists from the time before earth. According to Pak Din the bracelet works by raising your inner strength (tenaga batin or tenaga dalam) "depending upon the wood that you are using, so that you and the wood will reach God in the prayer."

The urobos is a familiar theme in Gnostic religion, and alchemy, the "science" of turning base metal into gold. Whan [2000] (2003) says the urobos is mentioned by Heidegger and Hegel in regard to hermeneutics, and the circular nature of knowledge, and claims: "The Urobos is an archetypal symbolic image of a serpent coiled in a circle and eating its own tail. It served as an emblem of alchemy, representing Mercurius and the process of transmutation. Feeding upon 
itself, the uroboric serpent symbolized unity. Jung understood it psychologically as a symbol for the integration and assimilation of the opposite - that is, of the Shadow" [2000] (2003: 115n.22).

This outline of the uroboric serpent fits the data I have acquired nicely in connection to silat, and can be clearly seen to have affinities with the kayu baha. To understand more clearly how these three themes interconnect, a brief discussion of the Malay concept of the "shadow soul" is required.

\section{The Shadow Soul}

In classical Malay ethnography, Malay animism has a sevenfold conception of the soul, but the elements of this have never been entirely clear (Endicott 1970: 78; Skeat [1900] 1984: 50n). The roh and the nafs have already been mentioned, but less is known about the shadow-soul or the reflection soul. However, the shadow-soul forms an important aspect of the belief systems of silat practitioners, and Sufi mystics. Silat practitioners wear black uniforms, and train at night to remind themselves that they are but shadows. Only Allah is "Reality," Adam is the "Shadow of Reality," and Mohammad is the "Life of Reality." Furthermore, "in the mystical world most fighters learn how to develop their shadow," to bring it to life so as to come to their "fighting aid" (Pak Din). A ritual is conducted using a coconut without its shell, which has been cut from the tree with a wooden knife, and a beeswax candle, from a hive the bees have left, picked on Friday. Given these two instruments, the guru silat can tell you "how to make your shadow [come] alive-you-speak like you, look like you. But not you." The shadow may be used to assist you when fighting, so that there are two of you. It is said that if the shadow gets a punch in, the injury is incurable. The shadow follows orders: "When you are not around you can let him sleep in your bed but not touch your wife. He does not need sleep, or sex, or food. When you die he will also die" (Pak Din).

The belief is that when God created this world, and the sun, he also created shadows. The shadow is there with or without light, and is there to help you in this world. Because of this, one can "produce it or make it your friend." As Pak Din says, "when you strike off the light it doesn't mean the shadow is not there." One may become aware of the shadow soul through many kinds of mystical practice, including staring in the mirror for a period of three to forty days (cf. Chambert-Loir 2002: 143). 


\section{Calling the Shadow}

In the Malay world there are three types of people who raise spirits: the shaman, the warrior (and disciples), and the black magic practitioner. In this context spirits may refer to the souls of dead people, or to the spirit of animals, or material objects, such as "stone, air, jungle, and earth." Earth, fire, air, and water are configured in terms of a four-element theory, or Islamic humoralism (Laderman 1983: 35-72; 1992: 272-289). Each element is attended to, or "guarded" by a jinn, an angel, and a blessing (shafa' 'at). What you call for makes all the difference. You may summon an old warrior to guide you in martial arts, or an old medicine man to guide you in medicine. In medicine this is known as ilmu Batara Guru. ${ }^{42}$ In this way you begin learning from someone you cannot see. For silat they call it the Sheikh-getting in touch with the master who can create movement within you (gerak). Among other things the Sheikh can take the form of a tiger, or of a bygone warrior.

Silat masters who have schools, seru the jinn of the earth, Panglima Hitam, to make sure the training ground is protected against intruders. Panglima Hitam will emerge as a shadow when no-one is practising in the gelanggang, to prevent outsiders from practising there. The same spirit can also be asked to look after the area around the house. It must be fed eggs, and benzoic gum (kemenyan) as if laying bait for a fish. Alongside these offerings a spell (jampi) or "mantra" must be said, such as the following: ${ }^{43}$

\section{Hai Datok Panglima Hitam: \\ Duduk mengadap bumi, Mendonga mengada langit. \\ Barang siapa, niat jahat kepada ku, Itu engkau punya bahagian. Hanya kemenyan dan telur ini, Makanan engkau, sekali sehaja.}

Hey Black Genie of the Ground:

Sit facing the earth,

Look to the sky.

Should anybody have bad intentions towards me, That is your part [He is yours]. Only this benzoic smoke and eggs, Is your food for this time. 
Guru silat Din is also an accomplished artist, and has produced paintings and sketches of Panglima Hitam, in black, so as to represent the shadow. The paintings are specifically designed to help the owner to "enter the black, to enter the shadow," and to bring forth the shadow of the warrior, when they call him. Pak Din says the shadow of the warrior "can be many things to many people," and that he is not necessarily an historical reality, just someone they have heard of, or an ancient warrior from myth or history. This is a new and innovative 'technology of enchantment' appropriate for people who don't have the time, knowledge or inclination to perform the old ways (Gell 1992). The old ways are now considered haram (taboo) in an increasingly self-conscious Islamic society, but many Malays like to know that the power is available to them "as a backup, in times of emergency" (Pak Din).

Thus seru, or calling the shadow, may be accomplished by several means, both traditional and modern, from the dances of silat such as the belebat, to lying in a grave, to appeals directed towards modern paintings.

\section{The Graveyard Ordeal}

Pak Sarin's practice derives from Silat Siluman Harimau (tiger style), originally from East Java. Here summoning the souls of the dead is accomplished in a much more frightening way than the methods so far discussed. After learning eleven of twelve juros, Pak Sarin's son Masri elected to undergo the graveyard ordeal (patigini), which meant he must lie in a grave for eight nights in a row. The ordeal is arduous as all the while the corpse ants (semut mayat) and mosquitoes are biting. On the last night he began to "see" things. First, a ghost of terrifying appearance, the face half smashed in and mottled with canker, the eye missing: a veritable zombie. Then, as he lay in the grave, a spirit appeared. Long and broad in face, with pointed ears, and long though not sharp teeth, it hovered above him, and then walked along his body. Jampi were recited to keep the evil genie away. Next, "the most difficult test" was the appearance of a naked beautiful woman. Masri says "you must not touch her" though she will attempt to seduce you, or you will "fail the test."

Once this ordeal is complete, a named ancestor will appear, in animal guise (a tiger or a crocodile are most common) to act as your familiar. Then, in times of pressing need, you may call this spirit into you in order to fight. Masri recounts how he called the spirit in Tanjong Pinang (Riau) when he was attacked by two muggers, and says that all of a sudden they were "kicked into the ground" by a large group of taxi drivers and others wielding sticks. Hence the ancestor exists beyond the body, given an identity that transcends death (Hallam et al. 1999). 


\section{Death of a Silat Master}

Death does not always, or these days even usually, occur with "exact time and style," even for great silat masters, and this reveals the aesthetic deathscape in disjunction with the experience of death in the hospital. Consider guru silat Wak Sarin, master of five silat styles and the graveyard ritual, a huge bear of a man, with a mane of thick hair almost down to his waist. Proud and strong, he owned a fleet of fishing boats anchored off one of the nearby Indonesian Islands of the Riau Archipelago. He smoked several packets of cigarettes a day, and according to the surgeon, died of lung cancer brought on by his earlier career as a deep-sea diver.

Shortly before his death I was with him in the hospital, massaging his cold blue feet, and I am sad to say how much he suffered over a six-week stay in the hospital. The surgeons shaved and then lopped off the top of his head like the crown of a boiled egg, to remove a tumor from his brain. When Wak Sarin awoke from the craniotomy, bald and with staple stitches that would make Frankenstein wince, he said to his wife: “Why didn't you let me die? I am a Muslim after all." Wak Sarin was a brave man who suffered quietly; he was prepared to die, but not in this way, like a puppet in the hospital. His acceptance of death was thwarted by medical intervention, albeit well-intentioned.

\section{Conclusion}

I have shown how aspects of silat practice and performance indexically embody magical symbols concerning life and death, reality and the shadow, and the four elements. These same symbols are also embodied in artifacts from Malay material culture that may be highly symbolic such as badges, or more iconic such as the snake bracelet. These themes point to further alchemical, depth-psychological, and hermeneutical studies, discussions of which are outside the remit of this essay (for example, Herzog 1983: 93-98). From this evidence it is it interesting to think of the guru silat as warrior shaman, or warrior-alchemist, and to affirm a common Gnostic root to contemporary magic stretching across the continents. ${ }^{44}$ The transformation effected through silat training is not literally gold from lead, but of "the polished heart" from the unclean, the clean whole self replacing the "dirty" partial self. Once this transition is accomplished there is no need to fear death.

The main theme that these indices lead to is that death is a perpetual transformation rather than a final end. Apparent opposites, such as life and death, male and female, good and evil, are like mirror images, or shadows, and are actually manifestations of the One. This is the structural level which all the icons, indexes, and symbols discussed above reflect or point towards: they are 
embodied in ritual practice and performance, and sedimented into virtual and material culture. Yet this One is not the community, not consciousness, nor God; rather this One engaged in selfconsumption is life itself. The western medical establishment's view of death, manifested in the hospital, is discordant with this belief, and results in a disjunction of deathscapes.

\section{Acknowledgements}

Roxana Waterson, Todd Ames, Ellis Finkelstein, and Julie Farrer read through drafts of my script and offered useful suggestions. Thanks are also due to Michael Roberts who encouraged me to turn my attention to noble death.

\section{Notes}

${ }^{1}$ Malaysian informants tend to use the term silat, to describe Malay martial arts. Following their use I employ the term 'silat' as a noun, and bersilat as a verb meaning "to play silat." Bersilat is derived from 'bermain silat', literally 'silat play', which is abbreviated to 'bersilat'. Pesilat refers to what Malays would call the "silat player," or practitioner. There are many problems of definition, semantics, and synonyms, and there is a formidable arsenal of terms used to refer to martial arts in Southeast Asia. Basically they are referred to as seni (art) silat, bersilat, ilmu silat (Rashid 1990), or seni-belidiri (self defence) in Malaysia, as silek in Sumatra (Pauka 1998), and, sidestepping a large set of variations, as pencak silat in Java, and Indonesia. For further discussion see Maryono (2002); Draeger (1972). Chinese kung fu fused with silat is known as kuntao, meaning "head/fist" in Hokkien dialect.

${ }^{2}$ Specifically, the silat styles discussed are 'Seni Silat Haqq Melayu', 'Silat Seni Hulubulang Melaka', Seni Silat Gayong Malaysia, and 'Silat Siluman Harimau'. I also mention 'silat Melayu', 'silat harimau', 'silat buaya putih', and 'silat bayang'.

${ }^{3}$ It might be objected that I have painted a peculiar view of Malay Muslims, who would prefer to be 'represented' in a more orthodox Islamic way. To these critics I would reply that the Islamic guru silat is hardly an ordinary person anyway: possessed of extraordinary skills and abilities they regard Islam as divided into four levels of learning that one must go through, yet co-exist within simultaneously, to accomplish a mystical state of transcendence. First, shari 'at, which as Winstedt notes, is "the outward mark of the religious and about which there is no secrecy." The second stage is tarekat, "the mystic path...enjoined by his spiritual guide for the Sufi novice." Hakikat, the third stage, refers to "the plane of truth." Fourth, ma rifat, "corresponds with the plane of perfect gnosis" (Winstedt [1925] 1993:75). Hence guru silat would regard these critics as at a lower level of religiosity. Here, of course, I am speaking of the self-avowed traditionalist guru silat, rather than the secular sports coach.

${ }^{4}$ This three tiered stratification provides a neat though simplified formula for a complex series of power relations and interactions (cf. Andaya, and Andaya 2001: 46-51; Gullick 1958: 21-22).

${ }^{5}$ Once the interview with the Angels of Death has taken place, in which one's good and bad deeds are weighed against each other, some say the torment of hellfire begins immediately. However, for Malays, the period in the ground is a liminal time between this life and the next, which will only be announced at the Day of Resurrection, when everyone comes back to life - in the appropriate animal form of their character (snakes, pigs, dogs, tigers, and so forth).

${ }^{6}$ This view is held by members of the Naqshbandi Sufi tarekat but is commonly espoused more generally in current Sufi discourse.

${ }^{7}$ Death is regarded with a series of emotions including horror, revulsion, and dread, but also fascination, and humour. In the Malay language (Bahasa Melayu) mati is the common term for 'dead', but 'to die' can also be more elegantly termed meninggal. Royal death is referred to by the term mangkat. Another term for 
'to die' is $j u d$, but there are also less polite expressions like "go and die" (pergi mampus), or even, in Singapore, kojol (goal).

8 'Deathscapes' occurred to me whilst I was attending a seminar by Dr. Maribeth Erb (2005), who mentioned 'socio-scapes' in relation to Flores tourism. Subsequently, I found the term 'deathscapes' has been used in archeology (Rainville 1999), geography (Hartig, and Dunn 1998; Kong 1999; Teather 2001), science fiction, and even in "death metal" music (Inner Deathscapes by VII Arcano). In an interview, Achille Mbembe says that "[b]y 'necropower', I have in mind the various ways in which, in our contemporary world, sovereign power imagines itself and is deployed in the interest of maximum destruction of persons and the creation of deathscapes, new and unique forms of social existence in which vast populations are subjected to conditions of life conferring upon them the status of living dead. Let me hasten to say that this is far from being a typically African phenomenon. Deathscapes have emerged in such faraway places as Bosnia, Chechnya, Palestine, Colombia, Sri-Lanka, or Kashmir. Recent U.S.-led wars in Iraq or in the Balkans can be characterized as such" (Mbembe 2002, cf. 2001).

9 Metcalf and Huntington (1991: 60), in a paragraph on Geertz (1960), say that "[f]or the Javanese, mortality does not seem to hold any great terror and they discuss it with little show of anxiety. In part, this calmness is due to a pervasive fatalism about dying; it is all in the hands of God." As Geertz says, at Javanese funerals there is an "almost languid letting go" [1960] (1976: 72). This holds fast for my Malay family, some of whom said "it is all in the hands of God" when I asked them what they thought about the Tsunami. Citing Geertz (1960: 69-74) Metcalf and Huntington say "the proper emotional state to be achieved" at a funeral is not one of crying, but "is called iklas, a 'willed affectlessness', an evenness of feelings from which the peaks of elation and the troughs of despair have been eliminated" (Metcalf, and Huntington 1960: 60). Compare this to Peletz who says “....women in Negri Sembilan are more centrally involved in the ritual washing of corpses (even though the imam oversees the washing of male corpses); and it is generally expected that women, but not men, will wail uncontrollably during funerals (even though all such outpourings of emotion are frowned upon)...." (1996: 250). However, women do not necessarily wail uncontrollably at Malay funerals, nor are they expected to do so, as wailing makes it more difficult for the deceased to pass on; the deceased, though dead, is still sentient, and can still feel pain and, presumably, sorrow. It really depends on who dies, and how close the family were to the deceased: in the event of the death of a child, or a newlywed, a emotive demonstration of grief is to be expected upon death, and prior to burial as the corpse is prepared.

${ }^{10}$ Previously, to be Malay one needed to be a Muslim, speak the language, and adopt local custom. The criterion of being born in the land was only added later. As Kahn (2001: 128 n.19) notes the definition of a Malay for The Federal Constitution is "a person who professes the Muslim religion, habitually speaks Malay, conforms to Malay custom and (a) was born before Merdeka (Independence) Day, in the Federation or Singapore or born of parents one of whom was born in the Federation or Singapore, or was on Merdeka Day domiciled in the Federation or Singapore; or (b) is the issue of such a person. (Article 160, cited in Syed Husin Ali, 1981: 2.)."

11 Theater director and performance theorist Philip Zarrilli (1998) found that the Indian martial art kalarippayattu provided the basis for actor training in kathkali theater in Kerala. Zarrilli set out to learn this martial art, and he calls the full immersion of the researcher into the performance genre "performance ethnography." I first learned silat from guru silat Ariffin from 1996-98 in London, and I went on to do ethnographic field research on Seni Silat Haqq Melayu from 1999-2003 in Malaysia. I have also studied silat with three other guru silat in Malaysia, and three in Singapore. This data collection was for my doctoral thesis entitled Seni Silat Haqq: A Study in Malay Mysticism. As it was impossible to rely solely upon verbal or written accounts I had to resort to a reflexive exegesis, which means that I found out as much as I could from a variety of sources, and then reported back to several different guru silat, over a period spanning five years to acquire more information. This is because the guru silat will not teach you anything you do not already know. Due to the inherent secrecy of silat, the performers, and the audience, may be unaware of the hidden function of the dance (cf. Rashid 1990: 64).

${ }^{12}$ I have no reason to doubt the veracity of this indigenous account, but it is an account, and not something I have personally seen, or experienced.

${ }^{13}$ In Malay (Bahasa Melayu) pak abbreviates pak cik meaning "uncle," mak abbreviates mak cik (aunt), and these are used as an honorific prefixes by silat elders, denoting a level of fictive kinship that is more formal than bang (from abang elder brother), or kak (from kakak elder sister). In Malaysia, many silat masters may instead prefix their name with cikgu (teacher) rather than guru silat, although the terms are used 
interchangeably. Many students simply refer to the teacher as "Pak" (said $p a$ " as the "k" is not aspirated in Malay). In Indonesia, guru silat may be called $I b u$ (mother) or Pak (father, from bapak).

${ }^{14}$ Appadurai extends Anderson's (1983) concept of 'imagined community' to 'imagined world', "that is the multiple worlds that are constituted by the historically situated imaginations of persons and groups spread around the world" (1996: 33).

${ }^{15}$ The literature regarding silat is growing steadily (for example, Anuar 1992; Cordes 1990; de Grave 2001; Draeger [1972] 1992; Gartenberg 2000; Hamzah bin Ahmad 1967; Ku and Wong 1978; Orlando 1996; Maliszewski 1996; Maryono 2002; Mohd. Anis Md. Nor 1986; Pauka 1998, 2002; Rashid 1990; Shamsuddin (forthcoming); Sheppard 1972:141, 1983: 104; Tuan Ismail Tuan Soh 1991; Wiley 1993; 1994; Wilson 1993). Useful discussions of silat are scattered across the literature concerning Southeast Asian theater and dance (de Zoete, and Spies 1952: 252-257; Fernando-Amilbangsa 1983: 34; Mohd. Chouse Nasuruddin 1995; Simatupang (n.d.). Silat is also discussed in books on Malay magic (Skeat [1900] 1984; Shaw 1976: 22-29; Werner 1986: 22-39).

${ }^{16}$ Aristocrat Tuan Ariffin Yeop Mahidin is bodyguard (hulubalang) to HRH Sheikh Rajah Ashman of Perak, Malaysia, and guru silat of the silat organization called Seni Silat Haqq Melayu, based in the U.K. I make no attempt to disguise informants: all mentioned here have given their permission to use their real names.

${ }^{17}$ Pak Din, guru silat of Silat Kuntao Melaka (formerly Silat Hulubulang Melaka).

${ }^{18}$ The term 'seni' (art) is used in Peninsular Malaysia to differentiate their silat from Indonesian 'pencak silat'. A discussion of silat terminology can be found in Maryono (2002: 2-9).

${ }^{19}$ I am referring here to Yang style tai chi, the most well known variety.

${ }^{20}$ Sembah is the name given to a short set of movements performed before the commencement of a silat class, and after its completion.

${ }^{21}$ Formally, colonial ethnographers such as Skeat referred to silat as "mock combat." There are ludic and agonistic elements in the practise of silat, but I prefer to address these within a dramaturgical framework, where 'the theater of combat' is the training ground (gelanggang), a place where defence, combat, and killing are "rehearsed', in the company of your "friends" (kawan), rather than your enemies (Huizinga 1950; Goffman 1960). Silat may be 'mock combat' but the training takes place late at night, in a deadly serious atmosphere. No questions may be asked during the instruction, and the students may only speak if spoken to by an instructor. The intense training and rituals of silat are punctuated by the occasional gaff, which breaks the tension somewhat. Apart from this, spectacular ludic outbursts of impromptu silat demonstrations occur after dramatic ritual ordeals, such as placing the hands into boiling oil.

22 'Jinn', in Arabic, means 'hidden'. The alam raib includes spirits from the Islamic pantheon such as jinn Islam (good Muslim spirits), and jinn kafir (evil non-Muslim spirits), as well as indigenous Malay beliefs concerning ghosts (hantu), faeries (bari bari), and vampires (pontianak).

${ }^{23}$ Parry (1982: 92), in regard to a good death in India says "[h]aving previously predicted the time of his going and set all of his affairs in order, he gathers his sons about him and-by an effort of concentrated will - abandons life. He is not said to die, but to relinquish his body." Similarly, Bradbury (1999) uses the terms 'good' and 'bad' death in the context of contemporary England.

${ }^{24}$ According to Errington social divisions in Southeast Asia are not a pyramid of nobles, freemen, commoners, and slaves. This commonly applied analogy is misleading as it shows horizontal breaks between the categories, and shows them as fixed like stone. "In fact the ties were far more vertical: high and low were (and are) allies, while peers in place were and still tend to be rivals" (Errington 1989: 97-98). Rather than a pyramidical analogy Errington (1989: 98) prefers to see these relations as analogous to an umbrella or as a cone of light cast from the ruler.

${ }^{25}$ On Hang Tuah see Errington 1975, and Sheppard 1964.

${ }^{26}$ The geliga embun looks like a pearl (or larger) and is found in the "heart" of the Lady's Mantis Tree.

${ }^{27}$ According to Dr Ames (personal communication), in seventeenth century Java men were known to insert small bells into their penis to give their sexual partners enhanced pleasure. Apparently, the bell could be heard as they walked along, thus announcing their potential (cf. Brown et al. 1988).

${ }^{28}$ Similarly the souls of the murdered are said to remain as graveyard ghosts (jimbalang orang) in (Endicott 1970: 74).

${ }^{29}$ Pak Din was called upon by the Malaysian government to verify that Mat Kilau was who he said he was - apparently he had died five times. Mat Kilau had a geliga embun inserted behind his ankle. 
${ }^{30}$ Laderman (1983: 17) uses the word 'cinabuta' in relation to Malay marriage practices, and following Winstedt (1972: 73) says that the term derives from the Sanskrit word meaning "the divider." Under Islamic law a man may not divorce and then remarry the same woman, unless the woman has been remarried and divorced again in the meantime. To expedite this process a cinabuta (blind Chinese) could be hired to marry the divorced woman, and consummate the marriage, only to immediately divorce her so the former husband may legally remarry her. Perhaps the husband's subsequent irritation (humiliation) is why the silat technique was invented! There is probably a sense of humour involved in naming a deadly silat technique "cinabuta."

${ }^{31}$ However, the head is not considered the seat of the soul, a familiar theme in anthropology where taking the head prevents the soul from entering the realm of the dead (cf. Parry 1991; Rosaldo 1980).

${ }^{32}$ Amok is often constructed as 'fanatical force' in the Malaysianist literature (Winzeler 1990: 96-122) and sometimes treated as if it were a unique 'cultural syndrome'. However, amok, far from being an individual, disorganized, and insane activity; may be mistaken with a coordinated, group form of violence, a "furor" (Dumézil 1970: 10) that is unleashed through invulnerability rituals, much in the way that the Viking berserkers, a term derived from berserkir, "bear shirt" in Nordic (Margeson 2002: 14), unleashed their violent emotions through rituals, possibly involving the consumption of hallucinogenic mushroomsprobably fly-agaric (Amanita muscaria).

${ }^{33}$ In the Muslim world burial should take place in daylight and preferably within eight hours of death.

${ }^{34}$ The souls depart when they hear the takbir "calling" them to go back. The call (Alla hu akbar) is repeated in melody, and begins after ishak prayer (about 8.00 p.m.), and continues through the night preceding Hari Raya. The appearance and disappearance of souls also occurs during the second yearly Muslim celebration to mark the Muslim pilgrimage, known as Hari Raya Haji.

${ }^{35}$ I first came across this symbol whilst learning Kung $\mathrm{Fu}^{35}{ }^{35}$ It is part of the secret knowledge of Chow's Family Praying Mantis Kung Fu, and thus part of the lore of the former Fukien Province Shaolin Temple in China.

${ }^{36}$ The Malay World (Nusantara) may be said to include Peninsular Malaysia, the Riau Archipelago, Singapore, southern Thailand, parts of the southern Philippines, and the coastal Malay communities of Borneo, Java, Aceh, Sumatra, and Sulawesi. Some extend it "from the Easter Islands in the east to Madagascar in the west" (Maryono 2002: 2). Benjamin (2003: 7) criticizes the extended notion of the Malay World as a device of contemporary Malay scholarship, and following Milner (1981) says the term "The Malay World" should be reserved for those regions which were historically ruled by a Malay Sultanate.

${ }^{37}$ Personal correspondence via email, 23 July 2004.

38 Peletz (1996: 205) says that: "Each of the elements of the body is symbolically associated with a particular sensory organ (earth is linked with the mouth, wind with the ears, fire with eyes, and water with nose). Each sensory organ is associated, in turn, with one of the four archangels (Mikail, Jabrail [sic], Israfil, Azrail), one of the four spirits that watches over us after we die (Chadi, Wadi, Mani, Manikam), and one of the four Caliphs (Omar, Ali, Osman, Abubakar). Each of these archangels, spirits, and Caliphs is also symbolically keyed to one of the four corners of the world...." (cf. Endicott 1970: 40-45; Laderman 1983).

${ }^{39}$ For reasons I am unaware of, the numbers 2,5 , and 7 are missing.

${ }^{40}$ Dhikr is a Sufi mystical practise involving the repetitive chanting, either silent or vocal, of the ninetynine names of Allah.

${ }^{41}$ Pak Hanafi Harimau - Pak Din's former teacher, lived to 103. On the day of the tamat (completion) you stay in the swamp until the tiger arrives (Pak Din describes this tiger scene vividly). So, with styles like silat harimau (tiger), and silat buaya putih (white crocodile), first they introduce you to the spirit.

${ }^{42}$ Errington states: "The extreme example of formlessness at the center, which to my mind clinches the thought that social geography is shaped under duress from the challenging Other, is the example of Batara Guru [said to be the first ruler of Luwu]" (1989: 282). Furthermore, "Batara Guru is the name for what is most formless and most potent, most invisible and unlocatable. Batara Guru is everywhere, and therefore nowhere; Batara Guru's place is so high he is place-less, unlocated and unlocatable; he is perfectly one, but perfectly without form" (1989: 283).

${ }^{43}$ This provides an interesting example of code switching - the politics of Islamic religious consciousness causes many linguistic transpositions.

${ }^{44}$ Ancient transnationalism: as demonstrated, for example, by Campbell 1974. 


\section{References}

Alatas, Syed Farid. 1985. "Notes on Various Theories Regarding the Islamization of the Malay Archipelago." The Muslim World 75 (1):162-175.

Al-Attas, Muhammad Naguib, Syed. 1963. Some Aspects of Sufism as Understood and Practised Among the Malays, ed. Shirle Gordon. Singapore: Malaysian Sociological Research Institute.

Andaya, Barbara Watson, and Leonard Y. Andaya. [1982] 2001. A History of Malaysia. 2 d ed.

Basingstoke, Hampshire: Palgrave.

Anderson, Benedict. [1983] 1991. Imagined Communities: Reflections on the Origin and Spread of Nationalism. Revised ed. London and New York: Verso.

Anuar Abd. Wahab. 1992. Teknik dalam Seni Silat Melayu. Kuala Lumpur: Percetakan Dewan Bahasa dan Pustaka.

Appadurai, Arjun. 1996. Modernity at Large: Cultural Dimensions of Globalization. Minneapolis and London: University of Minnesota Press.

Ariès, Phillipe. 1978. L'Homme devant la mort. Paris: Editions du Seuil.

Becker, Ernest. 1973. The Denial of Death. New York: Free Press.

Benjamin, Geoffrey. 1979. "Indigenous Religious Systems of the Malay Peninsula.” Pp. 8-27 in The Imagination of Reality: Essays in Southeast Asian Coherence Systems, ed. A.L. Becker and Aram A. Yengoyan. Norwood, New Jersey: Ablex Publishing Corporation.

- 2003. "On Being Tribal in the Malay World.” Pp. 7-76 in Tribal Communities in the Malay World: Historical, Cultural, and Social Perspectives ed. Geoffrey Benjamin and Cynthia Chou. International Institute for Asian Studies: The Netherlands, and the Institute of Southeast Asian Studies: Singapore.

Bloch, Maurice, and Jonathan Parry, ed. 1982. Death and the Regeneration of Life. Cambridge, London, New York, New Rochelle, Melbourne and Sydney: Cambridge University Press.

Bradbury, Mary. 1999. Representations of Death: A Social Psychological Perspective. London and New York: Routledge.

Brakel-Papenhuyzen, C. 1995. Classical Javanese Dance: the Surakarta Tradition and its Terminology. Leiden: KITLV Press.

Brown, Donald E., James W. Edwards, and Ruth P. Moore. 1988. The Penis Inserts of Southeast Asia: An Annotated Bibliography with an Overview and Comparative Perspectives. Center for South and Southeast Asia Studies, Berkeley: University of California.

Byrant, Clyfton D. et al., ed. 2003. Handbook of Death and Dying. 2 vols. Thousand Oaks, London, and New Delhi: Sage Publications.

Campbell, Joseph. 1974. The Mythic Image. Princeton, New Jersey, and Guildford, Surrey: Princeton University Press. 
Chambers, Quentin, and Donn F. Draeger. 1978. Javanese Silat: The Fighting Art of Perisai Diri. Tokyo, New York, and San Francisco: Kodansha International Ltd.

Chambert-Loir, Henri, and Anthony Reid. 2002. The Potent Dead: Ancestors, Saints and Heroes in Contemporary Indonesia. Australia and Honolulu: Allen and Unwin, and University of Hawai'i Press.

Chambert-Loir, Henri. 2002. "Saints and Ancestors: The Cult of Muslim Saints in Java." Pp 132-140 in The Potent Dead: Ancestors, Saints and Heroes in Contemporary Indonesia, ed. Henri Chambert-Loir and Anthony Reid. Australia and Honolulu: Allen and Unwin, and University of Hawai'i Press.

Cheah, Boon Kheng. 2003. Red Star Over Malaya: Resistance and Social Conflict During and After the Japanese Occupation, 1941-46. 3d ed. National University of Singapore: Singapore University Press.

Chittick, William C. 1992. “'Your Sight Today Is Piercing': The Muslim Understanding of Death and Afterlife." Pp. 125-139 in Death and Afterlife: Perspectives of World Religions, ed. by Hiroshi Obayashi. Westport, CT: Greenwood Press.

Cordes, Hiltrud. 1990. Pencak silat: Die Kampfkunst der Minangkabau und ihr kulturelles Umfeld. Ph.d. diss., University of Cologne.

de Groot, Jan Jakob Maria. [1910] 1969. On the Soul and Ancestral Worship. Vol. 4, Book 2 of The Religious System of China. 6 vols. 1892 - 1910. Leiden: Brill. Reprint by Ch'eng-wen Publishing Co: Taipei.

de Grave, Jean-Marc. 2001. Initiation rituelle et arts martiaux: trois ecoles de kanuragan Javanis. Paris: Association Archipel.

de Zoete, Beryl, and Walter Spies. 1952. Dance and Drama in Bali. London: Faber and Faber Ltd.

Draeger, Donn F. [1972] 1992. Weapons and Fighting Arts of Indonesia. 2d ed. Boston, Rutland, Vermont, and Tokyo: Tuttle.

Dumézil, Georges. 1970. The Destiny of the Warrior, trans. Alf Hilterbeitel. Chicago and London: The University of Chicago Press.

Eagleton, Terry. 1991. Ideology: An Introduction. London and New York: Verso.

Endicott, Kirk Michael. 1970. An Analysis of Malay Magic. Singapore: Oxford University Press.

Erb, Maribeth. 2005. Friends, Guests and Finding Good Fortune: Tourism and the Shifting Socio-Scapes of an Eastern Indonesian Town. Paper presented for the Department of Sociology Seminar Series: National University of Singapore.

Errington, Shelly. 1975. Study of Genre: Meaning and Form in the Malay Hikayat Hang Tuah. Ithaca, New York: Cornell University. 1989. Meaning and Power in a Southeast Asian Realm. New Jersey: Princeton University Press

Fernando-Amilbangsa, Ligaya. 1983. Pangalay: Traditional Dances and Related Folk Artistic Expressions. Philippines: Ayala Museum, for the Ministry of Muslim Affairs.

Gartenberg, Gary Nathan. 2000. Silat Tales: Narrative Representations of Martial Culture in the Malay/Indonesian Archipelago. Ph.d. diss., University of California at Berkeley.

Geertz, Clifford. [1960] 1976. The Religion of Java. Chicago: University of Chicago Press. 
Gell, Alfred. 1992. "The Technology of Enchantment and the Enchantment of Technology." Pp. 40-63 in Anthropology, Art and Aesthetics, ed. J. Coote and A. Shelton. Oxford: Clarendon Press.

1998. Art and Agency. Oxford and New York: Oxford University Press.

1998. The Art of Anthropology: Essays and Diagrams, ed. E. Hirsch. London and New Brunswick, NJ: The Athlone Press.

Goffman, Erving. 1961. Asylums: Essays on the Social Situation of Mental Patients and Other Inmates. New York: Anchor Books.

1974. Frame Analysis: An Essay on the Organization of Experience. Boston: Northeastern University Press.

Goldberg, Vicki. 1998. "Death Takes a Holiday, Sort Of." Pp. 27-52 in Why We Watch: the Attractions of Violent Entertainment, ed. Jeffrey Goldstein. Oxford; New York: Oxford University Press.

Gullick, John Michael. 1958. Indigenous Political Systems of Western Malaya. University of London: The Athlone Press.

Hallam, Elizabeth, Jenny Hockey, and Glennys Howarth. 1999. Beyond the Body: Death and Social Identity. London and New York: Routledge.

Hamzah bin Ahmad. 1967. Silat Terlak Nata: pesaka hulubalang Melayu. Kuala Lumpur: Dewan Bahasa dan Pustaka.

Hartig, Kate, V. and Kevin M. Dunn. 1998. "Roadside Memorials: Interpreting New Deathscapes in Newcastle, New South Wales." Australian Geographical Studies 36 (1):5-20.

Hawkins, Joyce M. 2003. Kamus Dwibahasa: Oxford Fajar, Inggeris-Melayu, Melayu-Inggeris. [Dictionary of English and Malay] 3d ed. Kuala Lumpur: Oxford University Press.

Hayslip, Bert Jr. 2003. "Death Denial: Hiding and Camouflaging Death.” Pp. 34-42 in Handbook of Death and Dying, Vol. 1 ed. Clyfton D. Byrant et al. Thousand Oaks, London, and New Delhi: Sage Publications.

Hertz, Robert. [1905-06] 1960. "Contribution à une étude sur la représentation collective de la mort."

Année Sociologique, X, pp. 48-137; see also in Sociologie religieuse et folklore, Paris, PUF, 1970 (1928), pp. 1-83; in English trans. "A Contribution to the Study of the Collective Representation of Death," in Death and the Right Hand, trans. R. and C. Needham, New York, Free Press, 1960.

Herzog, Edgar. 1983. Psyche and Death: Death Demons in Folklore, Myths and Modern Drama, trans. David Cox, and Eugene Rolfe. Dallas, Texas: Spring Publications.

Horowitz, Donald L. 2001. The Deadly Ethnic Riot. Berkeley, Los Angeles, and London: University of California Press.

Huizinga, Johan. 1950. Homo Ludens: A Study of the Play Element in Culture. London: The Beacon Press.

Kahn, Joel Simmons. 2001. Modernity and Exclusion. London, California, and New Delhi: Sage Publications.

Kapferer, Bruce. 2004. "Ritual Dynamics and Virtual Practice: Beyond Representation and Meaning." Social Analysis 48, no. 2 (Summer): 35-54. 
Keeler, Ward. 1987. Javanese Shadow Plays, Javanese Selves. Princeton, N.J: Princeton University Press.

Kong, Lily. 1999. "Cemeteries and Columbaria, Memorials and Mausoleums: Narrative and Interpretation in the Study of Deathscapes in Geography." Australian Geographical Studies 37, no. 1 (March): 1-10.

Ku Ahmad bin Ku Mustaffa, and Wong Kiew Kit. 1978. Silat Melayu: The Malay Art of Attack and Defence. Oxford, New York and Melbourne: Oxford University Press.

Laderman, Carol. 1983. Wives and Midwives: Childbirth and Nutrition in Rural Malaysia. University of California Press: Berkeley.

1992. “A Welcoming Soil: Islamic Humoralism on the Malay Peninsula.” Pp. 272-289 in Paths to Asian Medical Knowledge, ed. Charles Leslie and Allan Young. University of California Press: Berkeley.

Littlewood, Jean. 1993. "The Denial of Death and Rites of Passage in Contemporary Societies." Pp. 69-84 in The Sociology of Death: Theory, Culture and Practice, ed. David Clark. Oxford UK and Cambridge USA: Blackwell.

Maliszewski, Michael. 1996. Spiritual Dimensions of the Martial Arts. Rutland, Vermont and Tokyo: Tuttle.

Margeson, Susan M. [1994] 2002. Viking: Discover the Story of the Vikings, Their Ships and Weapons, Legends, and Sagas of War and Discovery. DK Eyewitness Books. London: Gallimard.

Maryono, O’Ong. 2002. Pencak Silat in the Indonesian Archipelago, trans. Ruth Mackenzie. Yogyakarta: Yayasan Galang.

Mbembe, Achille. 2001. On the Postcolony. Berkeley: University of California Press.

2002. Interview by Christian Hoeller, In Springerin Magazine, March.

http://www.multiworld.org/m_versity/articles/achille.htm/accessed 28 Feb. 2005.

Metcalf, Peter, and Richard Huntington. 1991. Celebrations of Death: The Anthropology of Mortuary Ritual. 2d ed. Cambridge: Cambridge University Press.

Milner, Anthony. 1981. "Islam and Malay Kingship." Journal of the Royal Asiatic Society: 46-70. Cited in Geoffrey Benjamin (2003) "On Being Tribal in the Malay World." Pp. 7-76 in Tribal Communities in the Malay World: Historical, Cultural, and Social Perspectives ed. Geoffrey Benjamin and Cynthia Chou.

Mohd. Anis Md. Nor. 1986. Randai Dance of Minangkabau Sumatra with Labanotation Scores. Kuala Lumpur: University of Malaya.

Mohd. Chouse Nasuruddin. 1995. The Malay Dance. Kuala Lumpur: Dewan Bahasa dan Pustaka, Kementerian Pendidikan.

Pauka, Kirstin. 1998. Theater and Martial Arts in West Sumatra: Randai and Silek of the Minangkabau. Athens: Ohio University Center for International Studies, Monographs in International Studies, Southeast Asia Series No 103.

2002. Randai: Folk Theater, Dance, and Martial Arts of West Sumatra. USA: The University of Michigan Press. CD-ROM.

Parry, Jonathan. 1982. "Sacrificial Death and the Necrophagous Ascetic." Pp. 74-110 in Death and the Regeneration of Life ed. J. Parry and M. Bloch. Cambridge: Cambridge University Press. 
Peirce, Charles Sanders. 1991. Peirce on Signs: Writings on Semiotic, ed. James Hoopes. Chapel Hill: University of North Carolina Press.

Peletz, Michael G. 1996. Reason and Passion: Representations of Gender in a Malay Society. Berkeley, Los Angeles, and London: University of California Press.

Rashid Razha. 1990. "Martial Arts and the Malay Superman.” Pp. 64-95 in ed. Wazir Jahan Karim, Emotions of Culture, a Malay Perspective. Singapore: Oxford University Press.

Rosaldo, Renato. 1980. Ilongot Headhunting, 1883-1974: A Study in Society and History. Stanford, California: Stanford University Press.

Rosenberg, Jerome, and Dennis L. Peck, 2003. "Megadeaths: Individual Reactions and Social Responses to Massive Loss of Life." Pp. 223-235 in Handbook of Death and Dying, Vol. 1 ed. Clyfton D. Byrant et al. Thousand Oaks, London, and New Delhi: Sage Publications.

Shah, Sayed Idris. 1956. Oriental Magic. London: Rider and Company.

Shamsuddin, Sheikh. 2005. Forthcoming. The Malay Art of Self-Defense: Silat Seni Gayong.

Shaw, William. 1976. Aspects of Malayan Magic. Kuala Lumpur: Yau Seng Press.

Sheppard, Mubin. 1964. The Adventures Of Hang Tuah. 5h ed. N.p.: Eastern Universities Press.

1972. Taman Indera: A Royal Pleasure Ground, Malay Decorative Arts And Pastimes. London:

Oxford University Press.

1983. Taman Saujana: Dance, Drama, Music and Magic in Malaya Long and Not-so-Long Ago. Malaysia: International Book Service.

Simatupang, R.O. [n.d.]. Dances in Indonesia. Indonesia: Jajasan Prarantja.

Skeat, Walter, William. [1900] 1984. Malay Magic: An Introduction to the Folklore and Popular Religion of the Malay Peninsula. Singapore, Oxford, and New York: Oxford University Press.

Teather, E.K. 2001. "The Case of the Disorderly Graves: Contemporary Deathscapes in Guangzhou." Social \& Cultural Geography 2, no. 2 (June): 185-202.

Tobing, L. 1956. The Structure of the Toba-Batak Belief in the High God. Amsterdam: van Campen. Cited in Roxana Waterson [1990] (1997) The Living House: An Anthropology of Architecture in South-East Asia.

Tuan Ismail Tuan Soh. 1991. Silat Sekebun: Seni Silat Melayu Dengan Tumpuan Kapada Seni. Kuala Lumpur: .Dewan Bahasa dan Pustaka Kermenterian Pendidikan Malaysia.

Waterson, Roxana. [1990] 1997. The Living House: An Anthropology of Architecture in South-East Asia. Singapore: Thames and Hudson.

Winzeler, Robert. 1990. “Amok: Historical, Psychological, and Cultural Perspectives.” Pp. 96-122 in ed. Wazir Jahan Karim Emotions of Culture: A Malay Perspective. Singapore: Oxford University Press.

Werner, Roland. 1986. Bomoh/Dukun: The Practices and Philosophies of the Traditional Malay Healer. Switzerland: The University of Berne Institute of Ethnology. 
Whan, Michael. [2000] 2003. "How to Square the Medicine Wheel: Jung's Use of the Mandala as a Schema of the Psyche" in Drawing the Soul: Schemas and Models in Psychoanalysis, ed. Bernard Burgoyne. London: Karnac.

Wiley, Mark V. 1993. "Silat Gayong: Seven Levels of Self-Defence.” Journal of Asian Martial Arts 2, no. 4: 76-95.

Wiley, Mark V. 1994. "Silat Kebatinan as an Expression of Mysticism and Martial Culture in Southeast Asia." Journal of Asian Martial Arts 3, no. 4: 38-45.

Wilson, James. 1993. "Chasing the Magic: Mysticism and Martial Arts on the Island of Java." Journal of Asian Martial Arts 2, no 2. 10-43.

Winstedt, Richard. [1925] 1993. The Malay Magician. Kuala Lumpur. Oxford and New York: Oxford University Press.

1972 An Unabridged Malay-English Dictionary. $6^{\text {th }}$ ed. Kuala Lumpur: Marican \& Sons Sdn. Bhd.

Zarrilli, Phillip B. 1998. When the Body Becomes All Eyes: Paradigms, Discourses and Practices of Power in Kalarippayattu, a South Indian Martial Art. New Delhi: Oxford University Press. 